\title{
Az Ammobates oraniensis (Lepeletier, 1841) (Aculeata, Apidae) Magyarország faunájában új faj
}

\author{
GEBEI LÓRÁNT ${ }^{1} \&$ JóZAN ZSOLT ${ }^{2}$ \\ ${ }^{1}$ Hortobágyi Nemzeti Park Igazgatóság, H-4024 Debrecen Sumen u. 2., Hungary, \\ email: lorantgebei@hnp.hu \\ 2H-7453 Mernye, Rákóczi F. u. 5., Hungary, email: jozan.zsolt@citromail.hu
}

GebeI, L. \& JózAn, Zs.: Ammobates oraniensis (Lepeletier, 1841) (Aculeata, Apidae) is a new record for the Hungarian fauna.

Abstract: In this paper, the new records, the general distribution and Hungarian habitats of Ammobates oraniensis (Lepeletier, 1841) are given.

Keywords: new record, habitat, host animal

\section{Bevezetés}

Gebei Lóránt 2019-ben és 2020-ban a Bihari-sík Természetvédelmi Tájegységben terepi munkavégzés során számos Aculeata faj egyikeként megtalálta az Ammobates oraniensis példányait (1. ábra). Ez a faj hazánk faunájára új.

\section{Eredmények és következtetések}

\section{Az Ammobates fajok magyarországi lelöhelyei}

Az Ammobates fajok ritkák. Európában 16 fajt tartunk nyilván. Ezek közül nyolc csak egy-egy, a többi is csak néhány országból ismert (Fauna Europaea). Magyarországon eddig három fajt találtak meg: A. punctatus, A. similis és az A. vinctus. A punctatus a homokterületeinken elterjedt, az $A$. similis két nagyon régi dél-dunántúli lelőhelyről ismert, az A. vinctus néhány régi lelőhelyét a Budai-hegyekből és Sukoróról említik (Móczér \& SCHWARz 1968). Az A. punctatus az utóbbi évtizedek faunisztikai kutatásai során előkerült Belső-Somogy néhány pontján (JóZAN 1996, 2015). Az A. vinctus fajt megtaláltuk a Villányi-hegységben és a Mecsekben (JózAn 2000, 2006). A Bihari-sík Természetvédelmi Tájegységen 2020-ben két helyen gyüjtötték (leg. Gebei L.). 


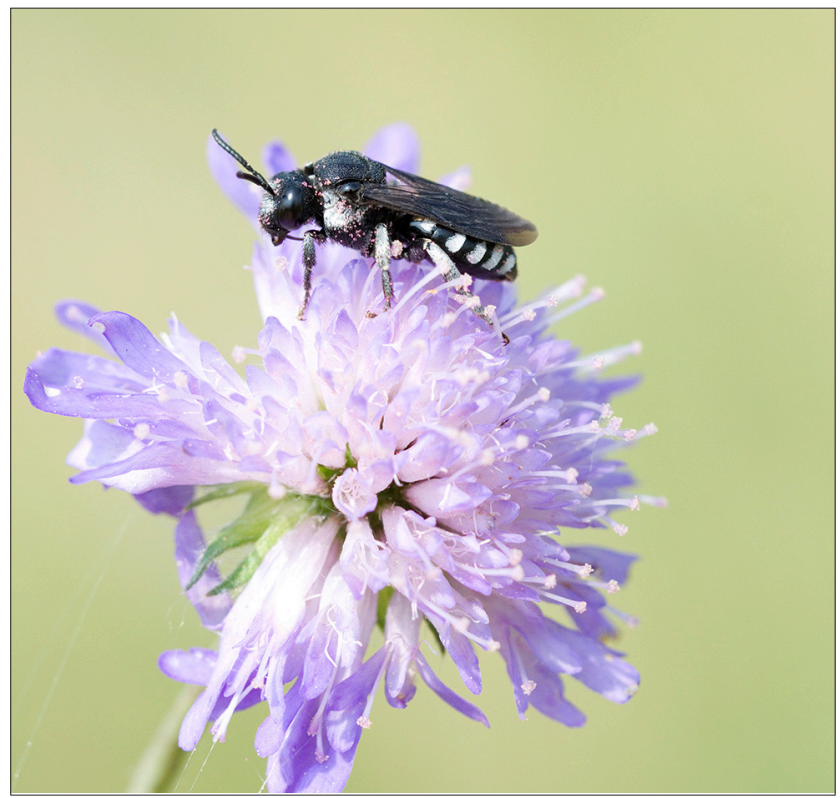

1. ábra: A nőstény Ammobates oraniensis (Lepeletier, 1841) táplálkozás közben

\section{Az Ammobates oraniensis elterjedése}

A Discover Life szerint ez a faj Észak-Afrika öt országában, Dél-Európa mindhárom félszigetén, Ukrajnában (Krím), Törökországban, Jordániában, Örményországban, Türkmenisztánban, Iránban él. A Fauna Europaea a kelet-palearktikumból is említi. Magyarországhoz legközelebb egy erdélyi lelöhelye ismert. A 19. század végén Vizaknán gyüjtötték (MóczÁR \& SCHWARZ 1968). Magyarország keleti területein való előkerülése valószínüsíthetö volt. A faj kleptoparazita, gazdaállataként Eucera fajokat figyeltek meg (E. dimidiata, E. algira, E. armeniaca) (VEREECKEN et. al 2012).

\section{Afaj élöhelye}

Gyüjtött példányok: Nagykereki: Körtélyes (EOV860809/208250), 2019. VII. 3. 1 nőstény (leg. Gebei L.); Zsáka: Mustó (EOV83229/197232), 2020. VI. 12. 2 nőstény (leg. Gebei L.). A példányok a Rippl-Rónai Múzeum (Kaposvár) rovargyüjteményében kerültek elhelyezésre.

Az A. oraniensis előfordulási helyei - az élőhelyeket tekintve - a 2019-es nagykereki és a 2020-as zsákai helyszínen is nagyon hasonlóak. Mindkét élőhely alapvetően nagyobb kiterjedésü szikes gyep. Itt mozaikosan megtalálhatók a füves vagy cickafarkos- és ürmös szikes puszta, foltokban sziki magaskórós növényzet és szikes mocsarak. A szikes gyepekben kis foltokban löszhátakat találunk, melyek nem is igazán emelkednek ki a tájból. Kétszikü növényekben gazdagok, főként a Salvia nemorosa, Stachys recta, Thymus sp., Knautia arvensis, Filipendula vulgaris, Dianthus pontederae fajok jellemzik. A nagykereki terület fajgazdagabb. Az A. oraniensis Nagykerekinél Cirsium vulgare virágán táplálkozott július elején, a szikes és löszös folt közötti aszatos területen. Ekkor már nem virágzott a Knautia sp. Júniusban Zsákán csak a Knautia arvensis virá- 
gait látogatták. Mindkét esetben csak a délután 16 óra körüli vagy utáni idősszakban lehetett találkozni velük. A Nagykerekinél begyüjtött példány is délután került elő. Mivel az összes állat nőstény volt valószínüsíthető, hogy a hímeket korábban, már májusban érdemes keresni. A valószínüsíthető gazdafajok közül a gyüjtőterületen csak a Tetralonia armeniaca fajt sikerült megtalálni. Nem messze a zsákai lelöhelytől megfigyeltünk néhány példányt a Vicia villosa virágain. A Knautia sp. virágán ekkortájt az Ammobates fajon kívül, főként néhány Bombus faj (Apidae) és az Andrena hattorfiana (Andrenidae) repült, később rendszeresen elöfordult a Scolia fuciformis (Scoliidae) is. Egyébként az Ammobates nagyon „békés”, táplálkozás közben viszonylag közelről meg lehet figyelni. Gazdaállat tekintetében talán érdemes még számításba venni a Tetralonia pollinosa fajt is, mert elöfordul mindkét fogási helyen.

\section{Irodalom}

JózAN Zs. 1996: A Baláta környék fullánkos hártyásszárnyú faunájának (Hym., Aculeata) alapvetése. Somogyi Múzeumok Közleményei 12: 271-297.

JózAN Zs. 2000: A Villányi-hegység fullánkos hártyásszárnyú (Hymenoptera, Aculeata) faunája. - Dunántúli Dolgozatok Természettudományi Sorozat 10: 267-283.

JózAN Zs. 2006: A Mecsek fullánkos hártyásszárnyú faunája (Hymenoptera, Aculeata). - Folia Comloensis 15: 219-238.

JóZAN Zs. 2015: A Barcsi borókás fullánkos faunája, III. (Hymenoptera: Aculeata). - Natura Somogyiensis 26: 95-108. https://doi.org/10.24394/NatSom.2015.26.95

Móczár, L. \& Schwarz, M. 1968: A Nomada-, Ammobates-, Pasites és Parammobatodes nemek faunakatalógusa (Cat. Hym. XXIII.). - Folia entomologica hungarica 23: 209-219.

Vereecken, N. J., de Premorel, G. \& Jacobi, B. 2012: Ammobates (Euphileremus) oraniensis (Lepeletier, 1841) and its host, Eucera dimidiata Brullé, 1832 in Crete (Hymenoptera, Aculeata). - Osmia 5: 15-18. https://doi.org/10.47446/OSMIA5.6

\section{websites}

Discovery Life bee species guide and world checklist, Ascher and Pickering: www.discoverlife.org/mp/20q last accessed 20. 10. 2020.

Fauna Europaea: all european animal species online - https://fauna-eu.org /cdm_dataportal/taxon - last accessed 20. 20. 2020. 
